\title{
Grendel's Motive in Attacking Heorot
}

Author(s): Oliver Farrar Emerson

Source: The Modern Language Review, Vol. 16, No. 2 (Apr., 1921), pp. 113-119

Published by: Modern Humanities Research Association

Stable URL: http://www.jstor.org/stable/3714908

Accessed: 31-05-2016 22:22 UTC

Your use of the JSTOR archive indicates your acceptance of the Terms \& Conditions of Use, available at

http://about.jstor.org/terms

JSTOR is a not-for-profit service that helps scholars, researchers, and students discover, use, and build upon a wide range of content in a trusted digital archive. We use information technology and tools to increase productivity and facilitate new forms of scholarship. For more information about JSTOR, please contact support@jstor.org.

Modern Humanities Research Association is collaborating with JSTOR to digitize, preserve and extend access to The Modern Language Review 


\section{GRENDEL'S MOTIVE IN ATTACKING HEOROT'1.}

LITTLE attention has been paid to the motive of Grendel's attack upon Heorot in Beowulf $89 \mathrm{f}$. In the only detailed account of his raids (Beow. 739-45) Grendel appears as a man-eating monster who seeks food, 'a full meal' (wyst-fylle 734), and who devours the body ravenously (743), as if hunger were his only thought. Nothing in the earlier account of his attack is at variance with this savage satisfaction of hunger, although it is there merely said that the first time he 'seized in their sleep thirty thanes' (122-3), and with the booty went to his home. In the third account of the event (1580-84), we are more exactly told that Grendel ate on the spot fifteen of the thirty victims, carrying the other fifteen away. During his attack of the following night, as we are informed in more general terms, Grendel 'accomplished more of murderous evil' (135-6). When the monster's mother comes to avenge her son (1278), she is discovered too quickly to make clear what she might have done. She has time only to seize 'one of the nobles' (1294) and the bloody hand of Grendel, when she hastens away to save her life. Escaping to the entrance of her watery cave, however, she too takes time to devour Eschere's body, but for some reason-a fortunate circumstance for her pursuers and perhaps intended as such by the poet - she leaves his bloody head upon the cliff (1420-21).

In curious contrast with all this fondness for a cannibalistic feastGrendel has the form of a man (1352)-we are told of the monster's making the attack because he 'bore hardly that he heard each day loud mirth in the hall' (88-9). This mirth is then described as 'sound of the harp' and 'song of the scop (minstrel),' while as an example of the latter there is repeated to us a hymn in praise of the Creator. Again, in lines 99-100, we are informed that when the attack was made 'men were living in happiness blessedly.'

This inconsistency between motive and accomplishment has not been commented upon before. Panzer, it is true, attempts to explain

1 This paper was written and sent to the Modern Language Review before Schücking's treatment of Beowulf in Paul and Braune's Beiträge xuvn, Part 3, had reached America. The later date proposed by Schücking for the poem, if accepted, would perhaps modify the writer's attempt to explain Beowulf 175-8, but the special point of this peper seems not to have been touched. 
Grendel's dislike of the Danish revelry on the basis of Teutonic folklore regarding elves and demons (Studien zur germ. Sagengeschichte, p. 264):

Grendels Eingreifen ward dadurch veranlasst, dass er die fröhliche Lust in Heorot nicht ertragen konnte. Das ist so allgemeine Dämonenart, denn nicht bloss Glockenklang scheucht die Elben, sondern all geräuschvolle Hantierung der Menschen, die Pochwerke im Gebirge, das Roden des Waldes und Bebauen des Ackers (Grimm, Mythol. 4. 380, W. Grimm, Kl. Sch. 1. 467) und in einer schleswigischen Sage (bei Müllenhoff' S. 289, Nr. 396) kommt der Elb nicht zu der Hochzeit, zu der er sich selber geladen, weil er 'die Trommelmusik nicht vertragen' kann. In unserem Epos stört Grendel die festliche Lust in Heorot augenscheinlich darum, weil sie auf seinem Grund, in seinem Reiche statthat. Wir fanden entsprechend im Märchen gerade in der Hausformel zweimal das Eingreifen des Erdmanns ebenso begründet: er zerstört die Prunkbauten, weil sie auf oder über seinem Reiche errichtet sind (oben S. 97, 98).

Such explanation, at first sight apparently so adequate, is in line with most Beowulf interpretation of the past. For years the poem has been considered scarcely more than a storehouse of heathen antiquities. Every time the word wyrd was found the antiquarian finger has come down with a 'There is genuine heathendom,' notwithstanding that references to luck or fortune are still common enough, without in the least disturbing general belief in an over-ruling Providence. Allusions to what might be thought Christian doctrine, for example lines 183-8, were explained away or regarded as interpolations. Special emphasis was laid upon the allusion to devil worship in lines 175-8, while thirtytwo uses of the word god in passages in which it might be explained as an allusion to the God of Christianity were slightly regarded ${ }^{1}$.

But the belief in Beowulf as mainly a heathen poem has been largely modified in recent times. The older view, persisting still in Blackburn's 'Christian Coloring in Beowulf' (Mod. Phil. XII, 205), was more than answered by the far-reaching paper of Klaeber, 'Die christlichen Elemente im Beowulf' (Anglia $\times x \times v-V I){ }^{2}$. A succinct statement of the newer view, that the poem was written by a Christian, appears in Gerould's Saints' Legends, p. 60. Noting more clearly than had been done before how the chronology of Old English literature would justify a Christian origin for the poem, he adds :

The Christian references in Beowulf, which have baffled all attempts at disentanglement as a whole, serve to confirm this view. They are there because the author, though he told a story of pagan times, was himself a Christian.

In this connexion let me insert a note on the devil worship in

1 Twenty-six of these references are in the part of the poem dealing with Hrothgar and his people, or with Beowulf in relation to those people.

${ }_{2}$ Compare Klaeber, 'Zum Beowulf,' Anglia xxvmr, 441 f. My own opposition to Blackburn's view was noted in 'Legends of Cain,' Publ. Mod. Lang. Ass. xxI, 916, and footnote. 
Beow. 175-8. In his Life of St Patrick (pp. 75-7), J. B. Bury thus accounts for the ease with which the Christian religion was accepted in Ireland :

Christianity, while it demanded that its converts should abandon heathen observances and heathen cults, did not require them to surrender their belief in the existence of the beings whom they were forbidden to worship. They were only required to regard these beings in a new light. For the Christians themselves, even the highest authorities in the Church, were as superstitious as the heathen....The fact, then, that the Christian Church, by its recognition of demons as an actual power with which it had to cope, stood in this respect on the same intellectual plane as the heathen, was an advantage in the task of diffusing the religion. The belief in demons as a foe with which the Church had to deal was expressed officially in the institution of a clerical order called exorcists, whose duty it was, by means of formulae, to exorcise devils at baptism.

Besides, not only did Christian missionaries in all parts of the world recognize the existence of heathen divinities as spirits of evil, but Augustine the missionary to the English was instructed by Pope Gregory the Great not necessarily to destroy heathen temples. The passage follows:

Cum vero vos Deus omnipotens ad reverendissimum virum fratrem nostrum Augustinum episcopum perduxerit, dicite ei quid diu mecum de causa Anglorum cogitans tractavi, videlicet quia fana idolorum destrui in eadem gente minime debeant, sed ipsa quae in eis sunt idola destruantur....Quia si fana eadem bene constructa sunt, necesse est ut a cultu daemonum in obsequium veri Dei debeant commutari, ut dum gens ipsa eadem fana non videt destrui, de corde errorem deponat, et, Deum verum cognoscens et adorans, ad loca quae consuevit familiarius concurrat ${ }^{1}$.

That this advice of Pope Gregory was known and followed in England is clear from the prominence Bede gives to it in his Ecclesiastical History, where it is quoted in Book I, chapter xxx. That heathen temples were preserved in England seems certain from the tradition, according to Plummer, that Ethelbert's heathen temple outside Canterbury was 'converted by Augustine into the Church of St Pancras.' Plummer also gives many references to both idols and heathen temples in England'.

Here, then, is important light on a passage which has often been misinterpreted. With heathen temples still remaining in early England, and doubtless not all converted to Christian uses, occasional lapses into heathen practices in times of special trouble may have occurred before the eyes of the Beowulf poet. He may therefore have introduced the

1 Sancti Gregori Magni Epistolarum Lib. xI, Epistola lxxvi Ad Mellitum Abbatem, Dat mandata Augustino, quem adibat, exhibenda, ad faciliorem Anglorum conversionem. Migne, Patr. Lat. 77, col. 1176.

2 Plummer's Bede II, 58, and the following note. Perhaps it is significant that Bede's chapter xxx of Book $I$ is omitted in the Old English version. In the England of King Alfred's time it may have seemed too much at variance with Christian practice. 
incident into the ancient tale, because his imagination was guided by realities of his own age. The incident is therefore not necessarily at variance with the generally Christian character of Hrothgar and the Danes. Indeed it may itself be regarded as another indication of the Christian character of the poet. Note especially that the god of the heathen fane is specifically called gäst-bona 'destroyer of souls,' that is devil, in accordance with accepted Christian belief.

To return to the attack of Grendel, only Klaeber in his article, 'Die christlichen Elemente' (Anglia Xxxv, 257), has given the suggestion of Christian colouring to the passage. Of it he says :

Die veranlassung seines feindlichen verhaltens ist-im einklang mit der märchendarstellung, vgl. Panzer, 264-das ihm verhasste fröhliche treiben in Heorot, $86 \mathrm{ff}$; das motiv des neides ist nur zwischen den zeilen zu lesen.

In a footnote he refers to Abbetmeyer's monograph, Old English Poetical Motives Derived from the Doctrine of Sin, p. 21 f., and adds the following references: Vesp. Hym. 12, hostis invidi dolo (=fiondes tes efestgan facne); Vita Quiriaci (Acta Sanctorum), omnium bonorum semper invidus diabolus, to explain $E l .899 \mathrm{ff}$; Gen. B. $421 \mathrm{ff}$., $733 \mathrm{ff}$., 750-60.

Excellent as this comment is, it seems to me not strong enough for adequate explanation of the motive of Grendel. That we should be told this man-eating monster was inspired to assail the Danes by envy of their happiness, rather than by hunger for human flesh, seems ridiculously insufficient. But the poet, as I suggest, intends to make all clear by immediately following the passage with his characterization of Grendel as a 'hellish fiend' (feond on helle, 101), and reciting at length his origin in the devilish progeny of Cain (lines 104-14), an origin which he again asserts in a later passage (1258-68). In other words, this is the reason for introducing a passage which has always been a stumbling block to those who saw only a heathen story in the poem, and which occasioned what now seems the extraordinary interpolation theory. As of devilish origin, Grendel merely exhibits a devilish characteristic in being carried away by envy of the happy Hrothgar and his court, a community accepting God as Creator and benefactor-in other words, essentially Christian.

It would seem scarcely necessary to argue at length for envy as a characteristic of the devil according to medieval conception. Envy of the Creator was joined with pride in his own powers to cause the fall of Lucifer. Indeed, St Augustine gave envy as the prime motive: 'Qui invidet, non amat. Peccatum diaboli est in illo; quia et diabolus in- 
vidiendo dejecit1.' Envy stands next to pride in the list of the seven 'deadly sins,' as in St Augustine's Tractatus de septem vitiis et septem donis Spiritus Sancti ${ }^{2}$, in Gregory the Great's Moralium Libris, and usually perhaps in medieval books. Compare for English works, Cursor Mundi 1. 27524 f.; Dan Michael's Ayenbite of Inwit; Jacob's Well; Lay Folks' Catechism; Chaucer's Parson's Tale; Gower's Confessio Amantis; William of Shoreham's Poems No. 4.

Envy of man's happiness was also fully recognized in medieval times as a devilish characteristic. Jewish legend, on which so much of Christian demonology was based, placed the envy of Adam and its accompanying jealousy before the fall of Lucifer:

The extraordinary qualities with which Adam was blessed, physical and spiritual as well, aroused the envy of the angels. They attempted to consume him with fire, and he would have perished, had not the protecting hand of God rested upon him, and established peace between him and the heavenly host. In particular Satan was jealous of the first man, and his evil thoughts finally led to his fall4.

For the same envy of man by the devil I need cite, among Christian writers, only two of the Church Fathers, one Greek and one Roman. St Chrysostom, in his forty-eighth Homily on John's Gospel (chap. 7, 1),

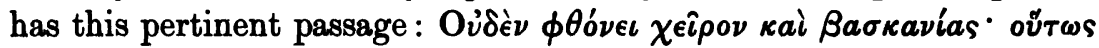

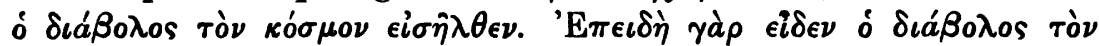

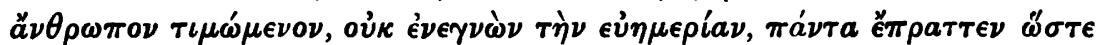
$a \dot{u} \tau \dot{\nu} \nu$ á $\nu \epsilon \lambda \epsilon \hat{\imath} \nu^{5}$. For the Roman Fathers St Augustine is equally clear in his presentation of the same idea; Enarratio in Psalmum 139, 6 $(140,5)$ :

Absconderunt superbi muscipulum mihi. Totum corpus diaboli explicavit breviter, cum ait, superbi.... Inde veniunt omnes seductiones et supplantationes. Hoc prior ipse diabolus voluit, qui cadens stanti homini invidit: et quia ipse amisit regnum coelorum, hominem illuc pervenire noluit (Gen. iii), et non vult; et id agit nunc, ut homo illuc non perveniat, unde ipse dejectus est. Quia ergo superbus est ipse, et ideo invidus quia superbus, omne corpus ipsius talium corpus est ${ }^{6}$.

The same idea is found in Old English writers, although the examples I now have are later than the composition of Beowulf. The first is from Alfric's Sermo de initio creaturae:

pa ongeat se deofol pæt Adam and Eva wæron to ry gesceapene pæt hi sceolon mid eadmodnysse and mid gehyrsumnysse geearnian ta wununge on heofonan rice

1 In Epistolam Joannis ad Parthos, Tract. v, cap. iii (Migne, Patr. Lat. 35, col. 2017). Cf. also St Isidore, Sententiarum Lib. II, cap. xxv (Migne, 83, 700): 'Invidus membrum est diaboli, cujus invidia mors introivit in orbem terrarum, sicut et superbus membrum est diaboli.'

2 Migne, Patr. Lat. 40, col. 1089.

3 Liber xxxi, cap. xlv, Migne Patr. Lat. 76, col. 620.

4 Ginzberg, Legends of the Jews I, 62.

S Migne, Patr. Graec. 59, col. 269.

- Migne, Patr. Lat. 37, col. 1807. 
We be of afeoll for his upahefednysse, pa nam he micelne gramum and andan to parn mannum, and smeade hu he hi fordon mihte ${ }^{1}$.

The second occurs in Wulfstan's Homilies:

Ac sona swa deofol ongeat pæt mann to oam gesceapen wæs, pæt he scolde and his cynn gefyllan on heofonum pæt se deofol forworhte Xurh his ofermodignesse, pa wæs him pæt on myclan andan, ongann pa beswican and gelæran, pæt se man abræc godes bebod ${ }^{2}$.

That Grendel's envy of the Danes did not show itself in tempting them to their spiritual fall, as commonly with the devils, was due to his belonging to the race of Cain's descendants, corporeal monsters with physical characteristics. According to medieval conception these corporeal demons, as I have shown in the article mentioned above, were blood-thirsty in the most literal sense. The passage is in the Clementine Homilies :

But they [those who sprang from the union of the sons of God and the daughters of men], on account of their bastard natures not being pleased with purity of food (the manna God has provided), longed after the taste of blood. Wherefore they first tasted Alesh ${ }^{3}$.

So far I have not considered the Hymn of Creation (Beow. 90-98) sung by the Danish minstrel as a reason for Grendel's attack. It is not a reason, I take it, because it praises the Creator, toward whom envy would have been natural on the part of any demon. The song is primarily an example of the peaceful pleasures of the Danish people, and probably not intended as an indication of how they 'lived blessedly' (99-100) in any Christian sense. On the other hand, the words 'lived blessedly' might have such meaning, especially as the hymn is in quite extraordinary contrast with the other songs of the scop introduced into the poem. The latter, as the Praise of Beowulf (872 f.) and the Song of Finn (1086 f.), are strictly in keeping with the natural characteristics of a warlike race. The only approach to the ideas of the Hymn of Creation are the words of the devout Hrothgar, as in lines $928 \mathrm{f}$. and $1700 \mathrm{f}$.

It may be contended that Grendel's dislike of the Danish revelry belonged to the original story. That is not impossible, and perhaps even probable. Even in that case, however, we must consider how a Christian poet of medieval England would have looked at such a matter, and how far he would have retained it if he had regarded it as essentially heathen. It is clearly not heathen to have the revelry of the Danes include a Hymn of Creation similar to that of the Christian

1 Homilies of Alfric, Elfric Soc. I, 16. Cf. also Elfric's Hexameron, ch. xvii.

2 Wulfstan's Homilies, ed. by Napier, p. 9.

3 Clementine Homilies 8, ch. 14-18, as translated in the Ante-Nicene Fathers 17, $142 \mathrm{f}$. 
Caedmon, whose follower the Beowulf poet must have been. Besides, the fact that the poet at once accounts for Grendel in exactly the manner in which the medieval Christian was wont to explain such monsters, leaves implications which cannot be accounted for on any heathen basis. The explanation of Grendel's motive as envy of man's happiness seems to account for the introduction of the Cain descent as it has not been accounted for before. With this explanation, that descent seems less than ever dragged in unnecessarily.

It was then, as our poet conceives, because Grendel was of devilish origin that he was prompted, by envy of the Danes in their happiness and innocent pleasures, to make his earliest attack, and to become their persistent enemy until the hero Beowulf comes to the rescue. Thus, at the foundation of this part of the Beowulf story, is a conception which can be fully accounted for only on a Christian basis. Let us add it to the Christian elements, as one of the significant evidences that only a Christian poet could have written the old English epic.

Oliver Farrar Emerson.

Cleveland, U.S.A. 